\title{
English Pronunciation Errors Made by Saudi Students
}

\author{
Islam Ababneh, (PhD) \\ University of Tabuk/KSA
}

Doi: 10.19044/esj.2018.v14n2p244 URL:http://dx.doi.org/10.19044/esj.2018.v14n2p244

\begin{abstract}
Arabs often pronounce many English words wrongly which leads to spelling and writing errors. This paper deals with English pronunciation errors made by two groups of native Saudi Arab speakers. The students in the first group are of English major while the students in the second group are of Arabic major. Generally, Arabic speakers use direct transfer and interference from Arabic in addition to stress shifts in their pronunciation that are not recognized stress patterns in English. Also, there are some sounds in English that have no equivalence in Arabic, which leads to vowel and consonant errors. This study identifies the pronunciation errors made by Saudi students in pronouncing words of problematic nature to Arabs in general. The students in both groups made vowel insertion and confusion, orthography, stress, intonation, errors; but the more trained students in group 1 made less errors than the students in group 2 .
\end{abstract}

Keywords: English pronunciation, Arabic, Saudi students

\section{Introduction}

In Saudi Arabia, Arabic is the dominant language of communication in almost all aspects of life and in all places: market, streets, parks, schools...etc. Arabic has twenty eight consonants and three pairs of short and long vowels phonemes. Each phoneme is orthographically represented by only one letter individually. Also, there is a one-to-one correspondence between phonemes and letters, which means that mostly Arabic speakers pronounce the words as they are written.

On the other hand, in phonemes terms, English has twenty four consonants, twenty vowels and diphthongs. English uses twenty six letters that represent all the phonemes. Also, there is no one-to-one correspondence between phonemes and letters; there are many ways to represent each phoneme. Smith (2007, p. 196) states that "English has 22 vowels and diphthongs to 24 consonants", while "Arabic has only eight vowels and 
diphthongs to 32 consonants. Also, one problem of English is that one letter might have different sounds; i.e. "car" and "caution". Tushyeh (1996) explained that Arabic has more of a one-to-one correspondence sound system where Arabic letters correspond closely to phonemes; differently from English that has about $85 \%$ of its words in regular spelling.

This research selects female students from two departments at the University of Tabuk and asks the participants to pronounce a set of words and phrases. Then it identifies and classifies the English pronunciation errors. All of the participants in the study are Saudi nationals since Arabs from distinct regions in the Arab world would make noticeably different consonants and vowel sounds. This is referred to as diglossia. Swan and Smith (2007, p. 195) state that diglossia creates some vernacular dialects which may vary in similarities and differences from one region to another. They point out that these differences between the vernacular Arabic dialects are more marked than differences between UK and US English. .Therefore, the study does not divulge into the different dialects of the Arabic speakers; it only examines a sample of Saudi students.

\section{Literature Review}

One of the essential language learning skills is pronunciation because it makes communication possible. Derwing \& Rossiter (2002) stated that the majority of English second language learners' main difficulty is learning how to pronounce; generally, learners consider pronunciation as the main cause for their communication problems.

Richards (1974) hypothesized about an "interlanguage" that sets between the learner's native (NL) language and the target language (TL) are L1 dependent and lead to errors caused by the first language transfer. These errors vary from one learner to another due to different variables, such as “...learning strategies, different training procedures, individual differences of teachers, text books..." (Jain, 1974, p. 189) and the interlanguage phase is temporary until the learner improves his/her performance which is inevitably based on his/her improved competence of the TL.

Dalton (2000) stressed that pronunciation is the "Cinderella of language teaching" when compared to other skills and components like grammar and vocabulary. Teaching proper pronunciation most often is not emphasized as grammar or vocabulary because many Arab teachers lack adequate phonetic skills or they simply consider other skills of the English language to be more important. Therefore, many learners will acquire sufficient grammar and vocabulary skills but they will not be able to carry on with normal conversations due to difficulties in pronouncing many English words. Also, many Arab learners of English have deep ingrained problems which they resist to change even with long exposure to English natives 
speaking conversations. The issue is more complicated by their teachers making fossilized pronunciation errors that they pass onto their students. Another problem is the direct transfer and interference from Arabic into the second language of English.

Errors are not the same as mistakes. Green and Tanner (1998, p. 93) state that a mistake is characterized as "a slip of the tongue"; that is, "the learner knows the correct form but has temporarily forgotten it". They also added that "There are several reasons why learners may make mistakes; for example, they may be tired, or not concentrating. Learners can often catch and correct their own mistakes". While Gass and Selinker (2008) give a contrasting definition of both errors and mistakes clarifying that "A mistake can be self-corrected, but an error cannot. Errors are "systematic," i.e. likely to occur repeatedly and not recognized by the learner. Hence, only the teacher or researcher would locate them, the learner wouldn't'.

Larry Selinker first introduced the term fossilization in 1972 . He defined it as: "Fossilizable linguistic phenomena are linguistic items, rules and subsystems which speakers of a particular NL will tend to keep in their IL relative to a particular TL, no matter what the age of the learner or amount of explanation and instruction he receives in the TL" (1972: 36). Selinker discussed some factors leading to the stagnation of interlanguage development including the age of learning, social identity and communicative need, etc.

The Encyclopedic Dictionary of Applied Linguistics defines fossilization as: The phenomenon whereby linguistic items (particularly erroneous ones) become permanent in a learner's Interlanguage. The term was used by Selinker (1972) in relation to the processes of 'levelling' (lack of forward movement) or 'regression' ('backsliding' where a learner's language reverts to an earlier stage). Fossilization may occur in relation to any linguistic level,' foreign accent' being the result of one form of fossilization. (p.135)

According to Selinker (1996), fossilization refers to the phenomenon that the language programs, grammatical rules and language subsystems related to the target language in interlanguage become stabilized in spite of the ages of learners and the quantity of the taught target language. And Richards et al. (2000) added that there are always incorrect language characteristics accompanied by the language learners' production in oral and written forms and an accent is typical of fossilization in pronunciation

In terms of the classification of fossilization, Selinker

divided fossilization into two categories, namely, individual fossilization and group fossilization. On the basis of its property, Selinker and Lakshmansn (as cited in $\mathrm{Li}$, 2003) divided fossilization into temporary one and permanent one. Littlewood (2000) identified two kinds of fossilization based on the observation of the characteristics shown in 
immigrants' dialects, naming individual fossilization and community fossilization.

As to the causes of fossilization, Selinker (1972) identified five leading factors : 1.language transfer ; 2.transfer of training ; 3.strategies of the second language learning; 4.strategies of the second language communication and 5.overgeneralization of IL linguistic material.. Then Selinker and Lamendella (as cited in LI, 2003) added that both intrinsic and extrinsic factors could account for the emergence of fossilization.

Liggett (1983, p. 34) defines EA as "... the study of learners' mistakes..., it starts from the demonstrated student errors". This definition clarifies that it is more of a study of the learner's errors than just comparing 2 languages without bearing the learner's situation in mind as a significant variable. Gass and Selinker (2008) support the same idea adding that error analysis is a "type of linguistic analysis that focuses on the errors learners make.

Kharma and Hajjaj (1997, p.14) explained that in contrast to the irregular spelling of English, Arabic is overwhelmingly regular. Moreover, to the learner, written English is not always a reliable guide to pronunciation, and they are often misled by the graphic representation of sounds.

Fisiak, Lipinska and Zabrocki, (1978) investigated the differences of the native language and the target language using contrastive analysis defined as "a subdiscipline of the linguistics concerned with the comparison of two or more languages or subsystems of languages in order to determine both the differences and similarities between them".

It was found in a study that Spanish and Arabic are, like English, intonational languages", Odlin (1997, p.119). The significance of intonation signals is that they indicate the speaker's emotions; they also provide hints of opening and closing, and turn taking in speech. According to the study by Keller-Cohen (1997), "A similarity in the suprasegmental patterns of two languages can give a learner important advantages in learning the syntax of the target language". This research will investigate the pronunciation errors committed by Arab natives; then it will classify the errors into fossilized and not fossilized ones. Odisho, 1979, p. 205) states that "English and Arabic are two languages that differ greatly in the range of syllable structure patterns they make use of". He concludes "Thus great interference is expected when English assumes the status of the target language for the native speakers of Arabic".

Zimmermann (2004) came with the table of words using the minimal pair /b/ and /p/ explaining that Arabic does not exhibit the voiceless stop consonant /p/, whereas English does. Similarly, Smith (2007, p. 197) explained the minimal pairs /f/ and /v/ what explains that the Arabic language 
does not exhibit the phoneme /v/, but unlike the /p/ case, Arabic does not exhibit the voiced phoneme.

Tushyeh (1996) explained that Arabs commit four types of language errors and one of them is the phonological error where the learners confuse /p/ and /b/; /f/ and /v/; /i/ and /e/. Tushyeh listed numerous intralanguage errors: simplification, overgeneralization, hypercorrection, faulty teaching, avoidance, inadequate learning and false concepts hypothesized.

Scott \& Tucker, 1974; Al-Kahtany, (1997) stated that Arabs suffer from diglossia where the public speak colloquial Arabic and not the "Fusha" or the Modern Standard Arabic.

There are errors that characterize certain Arab nationals among $22 \mathrm{Arab}$ counties. For example, Messiha (1985) explained that Egyptian Arabic learners face pronunciation problems with $/ \mathrm{p} /, / \mathrm{T} /, / \Delta /, / \mathrm{v} /$ and these sounds were represented as follows [b], [s], [s], [f] respectively. Barros (2003) confirmed the same results with Egyptian subjects. But, Messiha (1985) pointed out that some Arab speakers do not share the same difficulties with Egyptian speakers regarding the interdental fricatives.

Gordon (2005) reported that Ethnologue includes 35 varieties of Arabic. These versions of Arabic are scattered among 21 countries but are not restricted to Arab countries; they pass borders to other nations including Afghanistan, Cyprus, Malta and Uzbekistan. In the country of Saudi Arabia there are four dialects: Gulf, Hijazi, Najdi, and Standard spoken Saudi Arabian dialect.

Scott \& Tucker (1974) proposed that 23 cases of interference in spoken English by Arab learners is from colloquial Arabic as certain speakers of Arabic dialects produce different errors than speakers of other dialects.

Yost (1959: 115) explained that Syrian and Lebanese learners of English often have problems in distinguishing between certain sounds like [s] and $[\mathrm{t}]$. For example, the word chestnuts would be pronounced like [gostnust] by Syrian speakers of Arabic since [s] never follows [t] in the same syllable in Arabic. The author also stressed the influence of Arabic sounds on learners $^{\text {ee }}$ English by giving examples of vowel errors such as the word put pronounced as [put] and full turned into [ful]. In addition, Yost further explained the absence of some English phonemes in Arabic which were substituted by phonemes from the native language as in the following: /p/ became $[\mathrm{b}]$.

Barros (2003) concluded that Egyptian subjects make pronunciation errors that were different from errors made by subjects from Saudi Arabia and Kuwait.

Flege \& Davidian (1984) illustrated that phonological rules may be transferred from the first language (L1) inappropriately to the L2. In a phonetic comparison study of voiced stops produced by Saudi Arabs and by 
both American and Saudis in English. The authors concluded that when Saudis pronounced /b/ it was indistinguishable from /p/ to the native speakers of English.

Abdulwahab (2015) stated that some English consonants sounds do not exist in the Arabic like /p/,/y/ and /v/ and even these consonants, which seem similar to some Arabic consonants like $/ \mathrm{t} /$ or $/ \mathrm{k} /$, are not identical but different in the manner and even in the place of articulation. He explained that English /t/ is alveolar and aspirated in word initial position followed by a vowel like tea /ti:/where as the Arabic / $t$ / is dental and non-aspirated in the same word position like in /ti:n/.

Jalal Ahmad and Mohammad Nazim (2014) studied errors made by students of English as a Foreign Language (EFL) in pronouncing English words at Najran University and they concluded on the causes of these errors made by those learners

Al-Hattami (2010) highlighted the phonetic contradictions between English and Arabic. The author gave some examples of the contradiction: /p/ is a phoneme in English but not in Arabic; /t/ is alveolar in English but it is dental in Arabic language; /d/ is alveolar in English but it is dental in Arabic language; /c/ is a phoneme in English but it does not find place in Arabic, and $/ \mathrm{v} /$ is a phoneme in English but not in Arabic.

Al-Shuaibi (2009) studied the problems of phonology and revealed that Arabs have difficulties in pronouncing final consonant clusters, reduction, substitution, and deletion. The author concluded that these are the three prime factors of these clusters which are involved in the pronunciation process.

Altaha (1995) focused on pronunciation errors made by Saudi sophomores English students. He identified seven major pronunciation errors: first, replacing the sounds /p, v, e/ and /عə/ with the sounds [b, f, i] and [ə:], respectively, second, vowel insertion in words that contains a sequence of two consonants initially or inserting a vowel between the first two consonants in words that have a sequence of three consonants initially, third, the pronunciation of "silent" letters; fourth, pronouncing the letter c as [k] when it should be pronounced as [s]; fifth, pronouncing the voiced stop /g/ as a voiced affricate [dz] and vice versa; sixth, pronouncing the digraph $\mathrm{dg}$ as two phonemes medially; seventh, shifting the place of stress.

\section{Methodology}

This paper investigates the pronunciation errors committed by two groups of students in pronouncing selected problematic words in the English; more specifically, the study focuses on Saudi Arab students (one group majoring in English and the other group is non-English major). Fifty students studying in the same university were selected at random from two 
departments (English and Arabic) and they were asked to pronounce written words classified into five categories.

The study uses a mixture of quantitative and qualitative approaches. Gay, Milla and Airasian, (2009) explains the word quantitative implies massive dependence on statistics to interpret the data collected in this type of research. Therefore, quantitative research requires a large sample of participants to give reliable statistics about the investigated phenomena. On the other hand, Gay, Milla and Airasian (2009) details that unlike the quantitative method, the qualitative method does not rely on numbers or statistics but it is the collection, analysis and interpretation of comprehensive narrative and visual (i.e., non-numerical) data to gain insights into a particular phenomenon of interest.

The data (pronunciation errors) are collected by the researcher then categorized and analyzed. The data was obtained through a pronunciation sheet and the researcher's own experience of teaching the students. The students were in two groups: 25 students of English major currently studying in the department of languages and translation in their fourth year of study in the year 2016-2017; and the other group is 25 non-English major students from the department of Arabic in the same faculty. The students in the first group have completed various English preparatory skills courses and have taken English courses: grammar, translation, phonetics, error analysis, semantics...etc; while the students in the second group have only completed English skills (grammar, vocabulary, and general essay writing) courses as a requirement of the university. The students have lived in Saudi Arabia and attended public or private schools in the same area before coming to the university; other educational or lifestyle background of the students was not investigated. Therefore, mostly the students have similar educational background. The errors categories were:

i) vowel confusion \& vowel insertion

In this case, the participant confuses a vowel sound by another; for example, 'will' might be replaced by 'well', 'sale' by 'sell', 'late' by 'let' or irregular vowels. In inserting an extra vowel, the participant adds a vowel in the beginning of the word; for example, inserting an "i' before the word "smile' or "spend" or "school"

ii) written form (orthography)

In this case, the participant has problems with the written form of the word and in effect has difficulties with the pronunciation; for example, debt, lieutenant, laugh, dough, phase, deaf, or the way the /i/ is pronounced: lead, see, people, believe, key, quay, suffer

iii) replace a sound by another $(/ \mathrm{p} /$ and $/ \mathrm{b} /),(/ \mathrm{f} /$ and $/ \mathrm{v} /),(/ \mathrm{w} /$ and $/ \mathrm{v} /)$, ( /c/ and /k/), and ( /T/ and /TH/) 
The Arabic speaker in this case pronounces the /b/ sound instead of the $/ \mathrm{p} /$ sound; for example, lab, lap, pie, bye, cub, cup. Also, the speaker pronounces the /f/ sound instead of the /v/ sound; for example, pronouncing "fiery" in place of "very", village, video, vanilla. In Addition, the speaker pronounces the / $\mathrm{w} /$ sound instead of the /v/ sound; for example, pronouncing "vair" in place of "wait", invite, advice, will, vanilla. Furthermore, the speaker pronounces the /c/ or /ch/ sound instead of the $/ \mathrm{k} /$ sound; for example, pronouncing "character" in place of "karacter", comedy, commit, courage. The speaker pronounces the /T/ sound instead of the /TH/ sound; for example, the words "Think", "The".

iv) stress problems on more than one syllabi words \& stress on the $/ r$ / sound The speaker would miss the stress on the right syllabus of the word; for example, in words "written", "comfortable", "productivity", "believe", "above", "horizon", and "horizontal". Also, the speaker would add an extra stress on the /r/ sound; for example, in the words "peter", "rain", "press", "recent", and "practical". Stress shift may change the word class of an English word from a noun to a verb or vice versa as in the word present. It could be /'prez(ə)nt/ as a noun or /pre'z(ə)nt/ as a verb.

v) Linking \& Pausing \& intonation

The speaker fails to link two sounds or fails to pause between two sounds; for example, hotdog, go on, gentleman, rise, fall.

\section{Results and Discussions}

The students in both groups made numerous English pronunciation errors and the following subsections give the details of the specific types of errors:

\section{1 vowel confusion $\&$ vowel insertion}

In group 1, a number of students confused the /e/ sound with the /i, eI, æ/ sounds in words such as "well", "will", "sell", "let" and some pronounced the sounds $/ \varepsilon$, ai, ei, ai/ in place of the /i/ sound; while others have confused the /a/ sound with the /e, $\varepsilon, æ$ × sounds as in the words "late", "let", "sell", "sale"; in addition, some students have used the /o/, /ei/, /ae/ sounds in place of the /e/ sound in "sell", "sale", and "well". On the other hand, some students missed to pronounce a vowel or they have produced the wrong vowel pronunciation. Unexpectedly, the participants in this group added an " $\mathrm{i}$ " vowel before/after the word "spend", "smile", and "snake" while some could not pronounce the words "stairs" and "spend". Finally, most students in this group had problems with the / $\varepsilon$, ei/ sounds but all of them pronounced the familiar "school" word correctly. Table 1 shows the number of students who pronounced correctly and the number of students who had vowel confusion and insertion pronunciation problems in group 1 . 
Table 1 shows the vowel confusion and insertion problems (group 1)

\begin{tabular}{|c|c|}
\hline Word / \# correct & Pronunciation by students \\
\hline Well- /wel/17 & $-/ \mathrm{wIl} / 7, / \mathrm{wol} / 1$ \\
\hline Will-/wil/17 & /wel/ 5, /wail/1, /weil/ 2 \\
\hline Sale- /seil/ 20 & $/ \mathrm{scl} / 2, / \mathrm{s} 2 \mathrm{l} / 1, / \mathrm{sr}: 1 / 1$ \\
\hline Sell- /scl/11 & $/$ serl/ 3, /sil/ 2,/seil/ 2,/sæl/ 2,/sæli/ 5 \\
\hline Late- /leit/17 & $/ 1 \varepsilon t / 8$ \\
\hline Let- /let/11 & /lit/ 7,/leit/ 5 \\
\hline Smile-/smarl/14 & $/ \mathrm{sml} / 3, / \mathrm{smil} / 3, / \mathrm{sm} 3 \mathrm{l} / 5$ \\
\hline Spend-/spend/17 & /Isp3nd/ 4, /spind/4 \\
\hline Stairs- /stcəz/8 & /stæez/ 9,/staiz/ 5, /str3s/ 3 \\
\hline Snake- /snerk/10 & /snæk/ 8,/sæneık/4, no vowel 3 \\
\hline School- /sku:1/25 & \\
\hline
\end{tabular}

In group 2, more students had similar confusion problems with vowels than the students in group1; but also there was the additional errors of trying to pronounce all the letters in a word and not being able to pronounce the words at all. In addition, the students added the "i" vowel before the "spend" word or inserted an extra /a/ sound in "snake" and the /i/ before sound "school"; but many (not all) students pronounced familiar words correctly such as "school"; while they made vowel confusion errors in other words. Table 2 shows the number of students who pronounced correctly and the number of students who had vowel confusion and insertion pronunciation problems in group 2.

Table 2 shows the vowel confusion and insertion problems (group 2)

\begin{tabular}{|c|c|c|}
\hline Word/\# correct & Pronunciation by students & Notes \\
\hline Well- /wel/11 & $-/ \mathrm{wIl} / 10, / \mathrm{wail} / 4$ & \\
\hline Will-/wil/16 & /wail/6, /werl/ 3 & \\
\hline Sale- /seil/ 12 & /sail/ 4, /sæli/ 5, /slæI/ 4 & sound all letters \\
\hline Sell- /scl/11 & $/$ seil/ 2, /sil/ 2,,/sæl/ 2,/sælil 8 & \\
\hline Late- /leit/16 & /lait/9 & \\
\hline Let- /lct/14 & /li:t/ 11 & \\
\hline Smile- /smail/8 & /sm3l/ 7, /smaili/ 6 & No pronunciation-4 \\
\hline Spend- /spend/4 & /Isp3nd/ 8, /spænd/4 & No pronunciation-9 \\
\hline Stairs- /steəz/4 & /stairz/ 5, /starz/ 9 & No pronunciation-7 \\
\hline Snake- /snerk/3 & /snæk/ 8, /sænerki/4 & $\begin{array}{l}\text { sound all letters } \\
\text { No pronunciation-10 }\end{array}$ \\
\hline School- /sku:1/15 & /Jku:1/ 4 , /Isku:1/ 6 & Adding an "i" before school \\
\hline
\end{tabular}

\subsection{Written form (orthography)}

In this category, the written form of words creates difficulties for the pronouncer. In group 1, a good number of students correctly pronounced the /f/ sound in "phase" but missed the /f/ sound in "laugh" and used the /v/ sound instead. Also, the majority of students incorrectly pronounced silent sounds as the /b/ sound in "debt" or the /gh/ sound in "dough". Some students used the / $\mathrm{g}$, $v f, \mho \mathrm{v}, \mathrm{vt} / \mathrm{sounds}$ in place of the /gh/ sound. Also, the "tion" sound in 
cautious was problematic for more than two third of the students as they pronounced it with the /ts/, / Jəs/,/usəs/ sounds. Table 3 shows the pronunciation of problematic written form words by the students in group 1.

Table 3 shows the written form problems (group 1)

\begin{tabular}{|c|c|}
\hline Word/\# correct & Pronunciation by students \\
\hline Deaf- /d $\varepsilon f / 12$ & /dr:f/ 7, /darf/ 6(two vowels) \\
\hline Phase- /ferz/12 & /feIs/ 7, /væz/ 6 \\
\hline Debt- $/ \mathrm{d} \varepsilon t / 3$ & $/ \mathrm{d} \varepsilon b t / 22$ \\
\hline Laugh- /la:f/9 & /lart/ 4, /lзf/ 3, /læv/ 3, /læg/ 3, /la:f/ 3 \\
\hline Dough- /dəu/4 & /dəug/ 7, /dəuf/ 5, /dəuv/ 5, /dəut/ 4 \\
\hline Cautious- /'ko: $\int \partial \mathrm{s} / 7$ & /kæts/4, /ku」əs/ 8, /kəusəs/ 6 \\
\hline
\end{tabular}

In group 2, almost all the students missed to correctly pronounce the words "phase", "debt", "laugh", "dough", and "cautious" words or they could not give any pronunciation to those words. This result matches the perception that students in this group pronounce words as they are spelled just like Arabic. Thus, the words in this category are problematic as their spelling is different from their written form. Table 4 shows the number of students who pronounced correctly and the number of students who pronounced wrongly in the written form problems of group 2.

Table 4 shows the written form problems (group 2)

\begin{tabular}{|c|c|c|}
\hline Word/\# correct & $\begin{array}{l}\text { Pronunciation by } \\
\text { students }\end{array}$ & Notes \\
\hline Deaf- /def/0 & /dI:f/ 9 & Long vowel- No pronunciation-16 \\
\hline Phase- /ferz/0 & /feIz/ 11, /væz/ 8 & No pronunciation-6 \\
\hline Debt- /det/0 & $/ \mathrm{d} \varepsilon b t / 15$ & $\begin{array}{l}\text { all added t sound- No pronunciation- } \\
10\end{array}$ \\
\hline Laugh- /la:f/2 & /læv/ 2, /læg/ 11 & hard to sound- No pronunciation-10 \\
\hline Dough- /dəð/0 & /dəug/ 11, /dəuf/ 5, & No pronunciation-9 \\
\hline Cautious- /'ko: Øəs/0 & /kəusəs/ 6 & Hard to sound--no pronunciation 19 \\
\hline
\end{tabular}

\subsection{Replace a sound by another}

In this category, the students would give a wrong sound in place of the correct sound for a variety of reasons: repair strategy, difficulty .etc. In group 1 , expectedly, half of the students used the $/ \mathrm{b} /$ sound instead of the /p/ sound in words such as "lap", "pie", "cup"; while some students wrongly pronounced the /p/ sound in place of the /b/ sound in words such as "lab", "bye", "cub". The students in this group might have been aware of the persistent Arabic problem with the $/ \mathrm{p} /$ sound and tried to force wrongly the utterance of the $/ \mathrm{p} /$ sound. The students also used the /f/ sound instead of the /v/ sound in the words "very" and "vanilla"; but many of them gave the correct pronunciation to the words "village" and "video". There was no confusion on the parts of the students between the /v/ and /w/ sounds in the words "wait", "will", "advise", "invite" even though the students had some vowel problems in the same words. Half of the students in this group used the /ch/ sound instead of $/ \mathrm{k} /$ sound in 
"Christian" while all the students pronounced the $/ \mathrm{k} /$ sound in the words "character", "comedy", "commit", and "courage" even though they made vowel errors in the same words such as the $/ \mathrm{f} /$ sound instead of $/ \mathrm{ch} /, \mathrm{missing}$ the $/ \mathrm{r} /$ sound at the end or a word, and replacing the $/ \mathrm{g} /$ sound with the $/ 3 /$ sound, or replacing the /e/ with the /i/ sound. Also, nine students used the /Ig/ sound instead of the $/ \mathrm{d}_{3} /$ sound in the word "village". Positively, almost all the students pronounced the $/ \mathrm{t} / \mathrm{and} / \mathrm{th} / \mathrm{sound}$ correctly in the words "the" and "think". Table 5 shows the number of students who replaced a sound by another and the number of them who pronounced correctly in group 1.

\begin{tabular}{|c|c|}
\hline Word/\# correct & Pronunciation by students \\
\hline Lab- /læb/16 & $/ 1 æ p / 9$ \\
\hline Lap- /læp/13 & $/ 1 \mathfrak{a b} / 8, / 1 \mathrm{l}: \mathrm{p} / 4$ \\
\hline Pie- $/ \mathrm{paI} / 8$ & $/ \mathrm{baI} / 4, / \mathrm{bil} / 6, / \mathrm{bel} / 7$ \\
\hline Bye-/bai/14 & $/ \mathrm{paI} / 3, / \mathrm{ber} / 8$ \\
\hline Cup- $/ \mathrm{k} \wedge \mathrm{p} / 16$ & $/ \mathrm{ko}: \mathrm{b} / 9$ \\
\hline Cub- /k^b/15 & $/ \mathrm{ko}: \mathrm{b} / 10$ \\
\hline Fiery- /'farəri/16 & /veri/ 9 \\
\hline Very-/'verI/25 & /VI:rI/ 10 \\
\hline Village-/'vilidz/16 & /vilig/ 9 \\
\hline Video- /'vidi əひ/14 & /'vi:di, əひ/11 \\
\hline Vanilla-/va'nıla/8 & /fənıla/ 7, /vænl/ 4, /vənı:la/ 6 \\
\hline Wait-/wert/14 & /wart/ 11 \\
\hline Will-/wil/17 & /wel/ 5, /wail/1, /weil/ 2 \\
\hline Invite-/In'vart/18 & /In'vent/7 \\
\hline Advise-/əd'varz/10 & /adfaiz/ 4, ədvi:s/ 7, /dvars/ 4 \\
\hline Vanilla-/va'nilə/8 & /fənıla/ 7, /vænl/ 4, /vənı:la/ 6 \\
\hline Christian-/'krist Jən/13 & /' $\int \mathrm{rrst} f \partial n / 12$ \\
\hline Character-/'kærrktə/17 & /'kərrktə/8 \\
\hline Comedy-/'kpmidi/12 & /'ko:midi/ 13 \\
\hline Commit-/ka' mit/5 & /kæmit/ 9, /ko:mit/ 11 \\
\hline Courage- /'kırIdz/9 & /'kærıd3/ 7, /'ko:rrdd3/ 9 \\
\hline The-/ðə/18 & $/$ /еi/ 7 \\
\hline 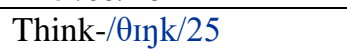 & \\
\hline
\end{tabular}

In group 2, only few students could produce the /p/ sound and many of them used the $/ \mathrm{b} /$ sound instead. Again, half of the students could not pronounce simple words such as "bye", "pie", "cub", "cup". Also, the students confused the /f/ and /v/ sound in the words "fiery", "very", "vanilla", "video". half of the students pronounced the "very" as " fi:ri ". In addition, the students could not pronounce other words such as "vanilla", " Christian", "character", "comedy", "commit". Almost all the students could not pronounce the word "courage". The students replaced the /k/ sound with the /c/ sound in words such as "recent" and pronounced it as /riknt/ or /riznt/. Table 6 shows the number of students who replaced a sound by another and the number of 
students who pronounced correctly in group 2 .

Table 6 shows replacing a sound by another (group 2)

\begin{tabular}{|c|c|c|}
\hline Word/\# correct & $\begin{array}{l}\text { Pronunciation by } \\
\text { students }\end{array}$ & Notes \\
\hline $\mathrm{Lab}-/ 1 æ b / 0$ & $/ 1 æ b / 25$ & All made errors \\
\hline Lap- /1æp/ 8 & /1æb/ 11, /1ı:p/ 6 & \\
\hline Pie- /pai/ 2 & /bai/ 12, /br:/ 9 & No pronunciation-2 \\
\hline Bye- /bai/ 4 & $/ \mathrm{paI} / 12$ & No pronunciation-9 \\
\hline Cup- $/ \mathrm{k} \Lambda \mathrm{p} / 2$ & $/ \mathrm{ks}: \mathrm{b} / 10, / \mathrm{kæb} / 4$ & No pronunciation-9 \\
\hline Cub- /kıb/ & $/ \mathrm{ko}: \mathrm{b} / 10$ & No pronunciation-15 \\
\hline Fiery- /' faiəri/0 & /veri/ 18, /væri/ 5 & No pronunciation-2 \\
\hline Very- /'veri/ 10 & /fi:ri/ 11 & No pronunciation-4 \\
\hline Village- /'vilid3/ 4 & /vilig/ 12, /filig/ 4 & g sound- No pronunciation-5 \\
\hline Video- /'vidi, əठ/ 6 & /'VI:dI, əv/14 & No pronunciation-5 \\
\hline Vanilla-/vo'nılə/1 & /fənıli/ 9 & No pronunciation-15 \\
\hline Wait-/wert/5 & /wpt/ 15 & $\begin{array}{l}\text { No mixing between the } \mathrm{w} \text { and } \mathrm{v}-\mathrm{No} \\
\text { pronunciation- } 10\end{array}$ \\
\hline Will-/wil/7 & /wel/ 9, /wail/6, /weil/ 3 & \\
\hline Invite- /In'vait/3 & /n'venti/12 & $\begin{array}{l}\text { sound all letters (the last letter) } \\
\text { No pronunciation-10 }\end{array}$ \\
\hline Advise-/əd'vaiz/ 1 & /odfaiz/ 13 & No pronunciation-11 \\
\hline Vanilla- /və'nılə/1 & /fənılı/ 9 & No pronunciation-15 \\
\hline 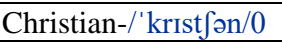 & 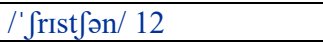 & Hard to sound- No pronunciation-13 \\
\hline Character-/'kærıktə/1 & $/$ 'kərr $\int \operatorname{tr} / 5$ & Hard to sound- No pronunciation-19 \\
\hline Comedy-/'kpmidi/0 & /'ko:midi/ 17 & Hard to sound- No pronunciation- 8 \\
\hline Commit-/kə'mit/0 & /ko:mit/ 11, /ko:mait/ 5 & Hard to sound- No pronunciation-9 \\
\hline Courage- /'k $\wedge$ ridz/0 & /'kærg/ 8 & Hard to sound- No pronunciation-17 \\
\hline Recent- /'ri:sªt/1 & /rı:knt/ 11, /ri:znt/ 7 & $\begin{array}{l}\text { Problem with c-(k or } \mathrm{z})-\mathrm{No} \\
\text { pronunciation- } 7\end{array}$ \\
\hline The-/ðд/ 11 & /ðё/ 14 & \\
\hline 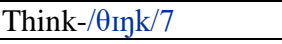 & /өæyk/ 18 & \\
\hline
\end{tabular}

In substituting sound by another, the speaker will tend to rely on the native Arabic language sound to pronounce English sounds. The /p/ sound is a voiceless and produced by lips and the speaker should push the air stronger outside the mouth. Arabs confuse the voiceless stop consonant/p/, which is not available in the Arabic language, with the voiced stop /b/ sound, which is available in the Arabic language and do this repair strategy when needed. Also, Arabs (including Saudi) have problems differentiating between the /v/ /f/ sounds as Arabic does not have a contrastive /v/ sound but sometimes it occurs as a variant of the /f/ sound. Therefore, many Arabic speakers have problems pronouncing the /v/ sound and often will produce the /f/ sound. Therefore, the absent English phonemes are substituted by phonemes from the Arabic native language; for example, the /p/ became $/ \mathrm{b} /$ and the $/ \mathrm{v} /$ becomes /f/. This study does not investigate sources of pronunciation errors but only sheds some light on general reasons behind those errors. 


\subsection{Stress problems}

One problem that faces the second language learners is missing to add a stress sound on some syllabus in a word or rolling or flapping of the /r/ sound. Kharma and Hajjaj (1997, pp. 24-25) simplify the English word stress patterns as follows:

(i) All one-syllable words, spoken in isolation , are stressed

(ii) A two-syllable word has one stressed syllable, on the first as in 'study, or on the second as in be'lieve.

(iii) Prepositions, like verbs, often have stress on the second syllable, e.g. a'bove.

(iv) If a word has a diphthong or a tense vowel, the stress often falls on it, e.g. ho'rizon.

(v) If there is no tense vowel or diphthong, stress often falls on the third short vowel from the end or the second from the end if followed by two consonants e.g. 'cinema, hori'zontal.

(vi) In words of three or more syllables there is usually one stressed syllable, but occasionally there may be two, e.g. ex'cessively or 'over'esteimate.

In group 1, in addition to vowel problems, most of the students missed the stress on the right syllable in words such as "written", "comfortable", believe", "above", and "horizon", "productivity", "horizontal", and "horizon". The students also made the errors of stressing the /r/ sound in words "peter", "rain", "press"; for example, almost all students pronounced "peter" as" p3tr". Table 7 shows the number of students who correctly stressed words and the number of them who missed to stress the words in group 1 .

Table 7 shows the stress problems (group 1)

\begin{tabular}{|c|c|c|}
\hline Word/\# correct & Pronunciation & Notes \\
\hline Written-/'rit ${ }^{2} \mathrm{n} / 11$ & /rai'tən/ 14 & Retain \\
\hline Comfortable- /'kımftəb ${ }^{\curvearrowright} \mathrm{l} / 14$ & /ks:mf'tæbəl/11, & $\begin{array}{l}\text { Come for a table (only } 2 \\
\text { syllables) }\end{array}$ \\
\hline Productivity-/,prod $\Lambda k^{\prime}$ tiviti/9 & /'prod $\Lambda \mathrm{k}$ tIviti/ 16 & Productive tea \\
\hline believe -/bi'li:v/17 & /'biləv/ 8 & be'lieve (2 syllabus) \\
\hline Above-/a'b $\Lambda \mathrm{v} / 6$ & $\begin{array}{l}\text { /2b' } 0: \mathrm{v} / \text { most of them- } \\
19\end{array}$ & $\begin{array}{l}\text { a'bove (stress on the } \\
\text { second syllable) }\end{array}$ \\
\hline Horizon-/hə' raIzª/9 & /h॰:ræ'zən/ 16 & $\begin{array}{l}\text { ho'rizon (stress often falls } \\
\text { on tense vowel) }\end{array}$ \\
\hline Horizontal- /, hpri'zpnt`1/13 & 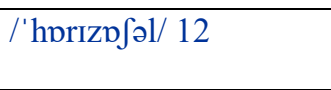 & $\begin{array}{l}\text { hori'zontal (stress on third } \\
\text { vowel) }\end{array}$ \\
\hline Peter-/'pi:tə/3 & /'p3tr/ all of them 22 & \\
\hline Rain-/reIn/11 & /rain/ 14 & \\
\hline Press- /pres/16 & /pris/9 & \\
\hline Practical-/'præktık²1/13 & $\begin{array}{l}\text { /præktfəl/ 5, /prækteıl/ } \\
7\end{array}$ & \\
\hline
\end{tabular}


In group 2, most of the students missed the stress on the right syllabus in words such as "written", "comfortable", believe", "above" and only few of them recognized the stress on the right syllabus; even some of them tried to sound silent letters such as the /w/ in "written". Almost all the students could not pronounce the words "productivity", "horizontal", and "horizon". Also, the students made similar stress /r/ problems on the words "peter", "press", "practical". Table 8 shows the number of students who stressed correctly/wrongly in group 2 .

Table 8 shows the stress problems (group 2)

\begin{tabular}{|c|c|c|}
\hline Word/\# correct & Pronunciation & Notes \\
\hline Written-/'rit ${ }^{2} \mathrm{n} / 7$ & /wrai'tən/ 18 & Retain (try to sound the w ) \\
\hline Comfortable- /'kımftəbəəl/1 & $\begin{array}{l}\text { /ko:mf' tæbəl/10, } \\
\text { /ko:mf' tæbəl' I/9 }\end{array}$ & $\begin{array}{l}\text { Come for a table (only } 2 \\
\text { syllables)- No pronunciation-5 }\end{array}$ \\
\hline Productivity-/,prod $\Lambda$ k'tıviti/ & Hard to sound & $\begin{array}{l}\text { Productive tea, No } \\
\text { pronunciation- } 25\end{array}$ \\
\hline believe -/bi'li:v/3 & /'biləv/ 8, /bi:laiv/ 9 & $\begin{array}{l}\text { be'lieve ( } 2 \text { syllabus)(long vowel } \\
\text { instead of stess) } 5\end{array}$ \\
\hline Above-/a'b $\Lambda \mathrm{v} / 1$ & /วb'ว:v/ most of them 20 & $\begin{array}{l}\text { a'bove (stress on the second } \\
\text { syllable) No pronunciation-4 }\end{array}$ \\
\hline Horizon-/hə' raiz ${ }^{\curvearrowright} \mathrm{n} /$ & Hard to sound & $\begin{array}{l}\text { ho'rizon (stress often falls on } \\
\text { tense vowel ). No } \\
\text { pronunciation- } 25\end{array}$ \\
\hline Horizontal- /, hpri' zpnt²l/ & Hard to sound & $\begin{array}{l}\text { hori'zontal (stress on third } \\
\text { vowel) } \\
\text { No pronunciation- } 25\end{array}$ \\
\hline Peter-/'pi:tə/5 & /'betər/ most of them 20 & \\
\hline Rain-/rein/2 & $/ \mathrm{rain} / 12, / \mathrm{r} \Lambda \mathrm{n} / 7$ & No pronunciation-4 \\
\hline Press- /pres/4 & /pri:s3s/ $11, /$ preIz/ 5 & No pronunciation-5 \\
\hline Practical-/'præktık'1/0 & /prækt」əl/ 9, /prækteıl/ 11 & No pronunciation-5 \\
\hline
\end{tabular}

\subsection{Linking \& Pausing \& intonation}

In group 1, half of the students made the error of pausing in "hot dog" but most of them rightfully paused in "go on". Also, a good number of them paused wrongly in "gentleman". Besides, all the students missed to use the intonation in the words "rise" and "fall". Table 9 shows the number of students who made correct/wrong linking, pausing, and intonation errors in group 1.

Table 9 shows the Pausing \& intonation problems (group 1)

\begin{tabular}{|l|l|l|}
\hline Word/\# correct & Pronunciation & Notes \\
\hline Hot dog 14 & Pause 11 & Correct: must link \\
\hline Go on 19 & No pause 6 & $\begin{array}{l}\text { Correct: must pause with w sound in } \\
\text { between }\end{array}$ \\
\hline $\begin{array}{l}\text { Gentleman- } \\
/ \text { 'dzent } / \text { lmən/17 }\end{array}$ & Pause 8 & \\
\hline Rise-/raiz/o & No 25 & Intonation (yes/no) \\
\hline Fall- /fo:1/ o & No 25 & Intonation (yes/no) \\
\hline
\end{tabular}


In group 2, almost all the students wrongly paused in the word "hot dog" and half of the students made errors of not pausing in "go on". All the students missed to use intonation in the words "rise" and "fall". Table 10 shows the number of students who made correct/wrong linking, pausing, and intonation errors in group 2.

Table 10 shows the Pausing \& intonation problems (group 2)

\begin{tabular}{|l|l|l|}
\hline Word/\# correct & Pronunciation & Notes \\
\hline Hot dog 2 & Pause (All) 23 & Correct: must link \\
\hline Go on 14 & No pause 11 & $\begin{array}{l}\text { Correct: must pause with w sound in } \\
\text { between }\end{array}$ \\
\hline Gentleman-/'dzent'lmən/ & Pause 8 & G sound- wrong pronunciation-17 \\
\hline Rise-/raiz/0 & No25 & Intonation (yes/no) \\
\hline Fall-/fo:1/ 0 & No25 & Intonation (yes/no) \\
\hline
\end{tabular}

\subsection{Causes of errors}

The sources of pronunciation errors might be the first native language since the speaker tries to transfer words and meaning of sentences to the second language. Lado (1957, in Gass and Selinker 2008, p. 89) testifies that individuals tend to transfer the forms and meanings, and the distribution of forms and meanings of their native language and culture - both productively when attempting to speak the language and to act in the culture, and receptively when attempting to grasp and understand the language and the culture as practiced by natives. Also, Faerch and Kasper (1987, in Mahmoud 2010, p. 127) conclude that "transfer is a psycholinguistic process whereby L2 learners activate their previous linguistic knowledge in developing or using their interlanguage". Mahmoud also adds that "transfer may be used as a learning strategy to formulate hypotheses about the target language and as a communication strategy to test these hypotheses". The causes of errors in each category:

1) replacing a sound by another

No doubt the most source of error in pronouncing English words is the lack of the phoneme in Arabic such as /p/, /v/, and the speaker will choose a close phoneme sound from Arabic as /b/, /f/; so there is an interference of the Arabic mother tongue on the learner pronouncing English.

2) confusion with vowel sounds

The vowel sounds in English are difficult and many while the vowel sounds in Arabic are simple and not many. Thus, the /i/ and the /e/ vowels in the words "sit" and "set" or in "will" and "well" are confused. The students could see "key" as "quay" and produce a complete different sound from the original word. Therefore, the variant pronunciation of the same vowel in different words creates difficulties. For example, "son", "come", and "among" have minor "o" sound that is hard to detect by learners. 
There are pronunciation problems related to differentiating the sound of have two vowels e.g. the students confuse /i/ with /i:/ as in sit, seat, and /o/ with /əu/ as in not, note and / æ/ with /ei/ as in mat, mate and /e/ with /ei/ as in let, late; also, in feat and boot where the first is pronounced as /ee/ and the second as /oo/. The words book, could are pronounced with the same /u/ sound.

3) stress problems

The speakers cannot decide where to add the stress (on what syllable); for example, the stress is on the first syllable (yesterday) and on the second syllable (tomorrow).

\section{Conclusion}

The findings of this study reveal that Saudi students struggle and confuse mainly the vowel sounds with another one or two phonemes vowel sounds such as the /e/ with /i/, /ie/, /ae/; the /i/ sound with / $\varepsilon$, ai, ei, ai/; and the /a/ sound with the /e, $\varepsilon, æ$ /. Also, the students have problems with missing sounds in Arabic such as the $/ \mathrm{p}$ v/ sounds and often replace them with the $/ \mathrm{b}$ f/ English sounds. In addition, the students completely missed the stress or intonations on two or more syllabi words and imitated the Arabic/r/ sound by added an extra stress on the English /r/ sound.

The findings also reveal that the types of errors among the two investigated groups are similar; but with more training the errors would be minimized as the English major students made less pronunciation errors than the Arabic major students. It can be noticed that the Arabic learner goes from imitating the Arabic mother tongue (pronounce as spelled) as was evident in group 2 to the persistent problems of replacing a sound by another $(/ \mathrm{p} /, / \mathrm{v} /$ with /b/, /f/) as done by more skilled students in group 2 .

As a recommendation the students should be exposed to native like setup in their classrooms by meeting native speakers of English or listening to native speakers on tapes and videos.

\section{Acknowledgment}

The author would like to acknowledge financial support of this work from the Deanship of Scientific Research (DSR), University of Tabuk, Tabuk, Saudi Arabia, under grant no S-1438-0221

\section{References:}

1. Abdulwahab, H. A. (2015). Difficulties of English Pronunciation Encountered by Saudi Learners, Unpublished M.A. Thesis, Open University of Sudan, Khartoum, Sudan. 
2. Ahmad, J. \& Nazim, M. (2014). Saudi EFL Learners views on English Pronunciation. Asian Journal of Studies and Social Studies. Vol. 2, No. 2, Pp. 355-366.

3. Al-Hattami, A. A. (2010). A Phonetic and Phonological Study of the Consonants of English and Arabic. Language in India. Vol. 10 : 5, Pp. 242-365

4. Al-Shuaibi, A. (2009). Phonological Analysis of English Phonotactics of Syllable Initial and Final Consonant Clusters by Yemeni Speakers of English. M.A. Dissertation, Language in India. Vol. 9 : 11, Pp. 195328

5. Gass, S. \& Selinker, L. (2008). Second language acquisition: an introductory course. 3rd ed. New York: Routledge.

6. Green, C. \& Tanner, R. (1998). Tasks for Teacher Education: A Reflective Approach (Coursebook). Longman

7. Kharma, N. \& Hajjaj, A. (1997) Errors in English among Arabic speakers: analysis and remedy. BeirutL Librairie du Liban

8. Liggett, M. (1983) Teaching English to Arabic Speakers: Methodology, materials development, and classroom management. Cairo: The American University Press.

9. Odisho, E. (1979). Consonant Clusters and Abutting Consonants in English and Arabic, Implications and Applications. Vol.7, pp. 205210. Pergamon Press Ltd.

10. Odlin, T. (1997). Language Transfer: Cross-Linguistics Interference in Language Learning. CUP.

11. Smith, B. Arabic Speakers (2007). In Swan, M \& Smith, B. Learner English: A teacher's guide to interference and other problems. Cambridge Handbook for Language Teachers. CUP.

12. Zemmermann, L. (2004) Teaching Pronunciation: A Specialist Approach. In Davidson, P., Al-Hamly, M., Khan, M., Aydelott, J., Bird, K., \& Coombe, C. Proceedings of the 9th TESOL Arabia Conference: English Language Teaching in an IT Age. Vol.8. Dubai: TESOL Arabia.

13. Derwing, T. M. \& Rossiter, M. J. (2002). ESL learners' perceptions of their pronunciation needs and strategies. System, 30(2), 155-166.

14. Richards, J. (1974). Error Analysis: Perspectives on Second Language Acquisition. London: Longman.

15. Jain, M P. (1974). Error Analysis: Source, Cause and Significance. In Richards, J. (1974). Error Analysis: Perspectives on Second Language Acquisition. London: Longman.

16. Tushyeh, H. (1996). Linguistic Problems Facing Arab Learners of English. Review of Applied Linguistics, 111-112(May), 109-117. 
17. Scott, M. S. \& Tucker, G. R. (1974). Error Analysis and EnglishLanguage Strategies of Arab Students. Language Learning, 24(1), 6997.

18. Messiha, G. Z. (1985). Some Phonological Problems That Face Arab Learners of English. Studies in African Linguistics, 9(Dec), 224-227

19. Barros, A. M. (2003). Pronunciation Difficulties in the Consonant System Experienced by Arabic Speakers when Learning English after the Age of Puberty. Unpublished master"s thesis, West Virginia University

20. Flege, J. \& Davidian, R. (1984). Transfer and developmental processes in adult foreign language speech production. Applied Psycholinguistics, 5, 323-347.

21. Scott, M. S. \& Tucker, G. R. (1974). Error Analysis and EnglishLanguage Strategies of Arab Students. Language Learning, 24(1), 6997.

22. Yost, G. (1959). Syrian English. American Speech: A Quarterly of Linguistic Usage, 34(2), 109-15.

23. Gordon, Raymond G., Jr, (ed). (2005). Ethnologue: Languages of the World, Fifteenth edition. Dallas, Tex: SIL International. Online version: http://www.ethnologue.com/

24. Barros, A. M. (2003). Pronunciation Difficulties in the Consonant System Experienced by Arabic Speakers when Learning English after the Age of Puberty. Unpublished master"s thesis, West Virginia University.

25. Altaha, F. M. (1995). Pronunciation Errors Made by Saudi University Students Learning English: Analysis and Remedy. Review of Applied Linguistics, 109-110, 110- 123.

26. Lado, R. (1957). Linguistics Across Cultures: Applied Linguistics for Language Teachers. University of Michigan Press.

27. Faerch, C. \& Kasper, G. (1987). Perspectives on Language Transfer. Applied Linguistics 8, 111-36 